co-ordinate system. Books on relativity usually say simply that a moving clock runs slow by a particular factor, leaving it to be inferred that anything that ticks and moves a pointer round a dial will visually display the Lorentz transformation. It was the purpose of my article to show by examples that this was incorrect, and to discover to what 'clock' the transformation formula applied.

Prof. Campbell maintains that in using a moving mass-clock the observer must move with the clock when measuring the mass but remain stationary when counting the grains. Why this difference? If he consistently moved with the clock he would obviously observe no effect of motion at all, but the action which Prof. Campbell prescribes for him seems a little arbitrary. I suspect that Prof. Campbell has not completely shed the idea of absolute motion; otherwise I cannot account for his allowing $N$ and $N^{\prime}$ to differ. It is perhaps as well to point out again that, according to relativity, if an observer is initially at rest with respect to two identical instruments, and then one of them moves away from him, the 'change' in the indications of that instrument is exactly the same as if it were undisturbed and the observer, with the other instrument, moved with the same speed. Which is $N$ and which $N^{\prime}$ in that case ?

Finally, Prof. Campbell seems to me to be quite wrong in objecting to, say, my mass-clock measurements on the ground that "Without the Lorentz equations there would be no basis for making such measurements". You do not need the Lorentz equations in order to measure mass. The principles of mass measurement were defined before the Lorentz equations were thought of, and they are not to be changed because the observer decides to move while applying them.

Imperial College,

London, S.W.7.

Feb. 15.

\section{Unusual Ice Formation in Wiltshire}

ON January 28 and 29 , ice was formed in west Wiltshire under conditions unprecedented in the experience of local inhabitants: a record of the effects may have more than local interest.

January 27 had been a day of relative warmth and of heavy rain after a prolonged spell of frost



[Photo by 0. W. Davies and sunshine, and water collected over the frozen ground. The early morning of January 28 was also wet, there being a mild drizzle; but water was freezing under foot and the branches of trees crackled. By midday, though rain continued, ice had become a conspicuous feature of the landscape. Blades of grass were embedded in needle-like sheaths, the taller stems in glass-like rods, and dead flower heads had given rise to ice flowers of beauty and delicacy. On hedgerows and trees, on roads, stone walls and wire fences, the same process was at work. Everything, including threads of hair entangled on barbed wire, had become thickly coated; and trees acquired a fantastic appearance suggesting giant candelabra of crystal.

By January 29 the ice had thickened. Grass blades were no longer encased in needles but in thick fingers of ice, and fields became most uncomfortable to walk over. Where grass stood high amid erect heads of dock, plantain, napweed, yarrow, etc., they had become a growth of brittle ice-bound stems. The weight of ice on trees and telegraph wires was now overwhelming and large boughs crashed to the ground.

Accurate measurements of the ice were not made. It was formed on the exposed and on the upper sides of supporting surfaces. In section, the fingers of ice were roughly elliptical, the original support occupying a position near the periphery in the longer axis. Around telegraph wires the ice was, however, circular (circa $\frac{3}{4}$ in. in diameter) which suggests the wires had undergone torsion. Icicles hung from some of the trees and from the eaves of buildings, but were not a conspicuous feature of the landscape.

Since the above was written a similar account of the same storm at Petersfield has been published by Cave'. Comparison of the two suggests that ice formation in Wiltshire started some twelve hours later but followed the same course. Storms of the kind are evidently rare though on record ${ }^{2,3,4}$ and information is scanty on their causative factors, on the growth of the ice, and on its effects upon living vegetation. The report ${ }^{5}$ that on March 5 New York experienced the worst ice-storm for 25 years is also of interest. E. R. GunThFr.

c/o British Museum (Natural History), London, S.W.7.

${ }^{1}$ Cave, C. J. P., An Ice Storm, The Times, February 13, 1940.

${ }^{2}$ Piebourg, P., Sur les effets produits, à Fontainbleau, par le verglas des 22, 23 et 24 janvier 1879 , Compt. Rend. Acad. Sci., 1, 245 des 22,

${ }^{3}$ Godefroy, L., Le verglas du mois de janvier 1879, Compt. Rend. Acad. Sci., 1, $244(1879)$. Pattinson, J., and Dines, J. S., Glazed Frost, January 1940, Met.
Mag., 75, No. 889, p. 12.

${ }^{5}$ The Times, March 6, 1940.

\section{Witwatersrand Local Tremors}

IN an article on "The Earthquake in Turkey" Mr. E. Tillotson refers to the idea that violent earthquake shocks appear to be followed almost immediately by sympathetic shocks in various parts of the world. In this relation he points out that on the same day as that on which the earthquake occurred in Turkey, December 27, 1939, earthquakes occurred in San Salvador, Los Angeles, Tangier and "Between December 27 and 28, twenty-five earthquakes and earth tremors... shook the gold mining district of the Rand near Johannesburg in South Africa". 